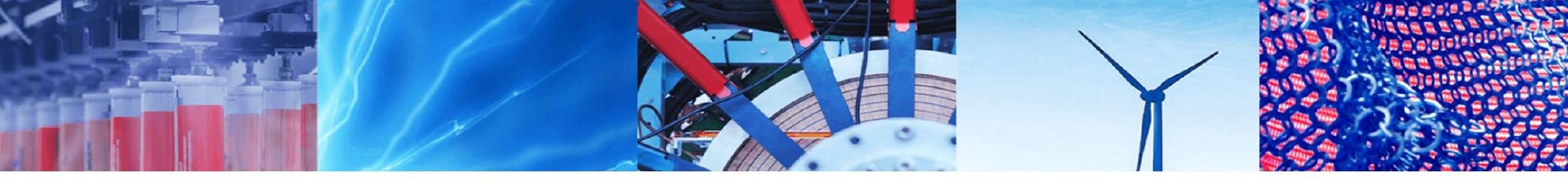

Research Article

\title{
Preparation of bimetal-based FeNi-N/C catalyst and its electrocatalytic oxygen reduction performance
}

\author{
Wei Fang ${ }^{1} \cdot$ Lu Liu $^{1} \cdot{\text { Ruiming } \mathrm{Li}^{1} \cdot \text { Rong Zhang }^{1} \text { (D) } \cdot \text { Wenyang Wang }}^{1} \cdot$ Ding Zhang $^{1} \cdot$ Zixiang Cui $^{1}$
}

Received: 5 November 2019 / Accepted: 30 March 2020 / Published online: 7 April 2020

(c) Springer Nature Switzerland AG 2020

\begin{abstract}
A kind of bimetal-based FeNi-N/C catalysts were prepared by combining ultrasonic reaction and high temperature heat treatment using dicyandiamide (DCD) as nitrogen source, $\mathrm{FeCl}_{3} \cdot 6 \mathrm{H}_{2} \mathrm{O}$ and $\mathrm{Ni}(\mathrm{OAC})_{2} \cdot 4 \mathrm{H}_{2} \mathrm{O}$ as bimetal source, $\mathrm{BP} 2000$ as carbon carrier. The composition and structure of the catalysts as-prepared were characterized by XRD, FT-IR and XPS. The catalytic activity of the catalysts on the oxygen reduction reaction(ORR) under alkaline conditions were tested by using linear sweep voltammetry (LSV) with a rotating disk electrode, and the prepared conditions, active site composition, the stability and methanol resistance of the as-prepared catalysts and the kinetic ORR mechanism were studied successively. The results show that the best FeNi-N/C-800 catalytic activity for ORR with the onset potential of $0.965 \mathrm{~V}$ (vs. RHE). The number of transferred electrons in catalytic ORR process is between 3.59 and 3.98 , indicating the $4 \mathrm{e}^{-}$dominated ORR mechanism and a direct conversion process from $\mathrm{O}_{2}$ into $\mathrm{H}_{2} \mathrm{O}$. The nature of the metal and the heat treatment temperature are important key factors in the preparation of the catalyst. From this work, $\mathrm{Ni}$ can be regarded as a catalyst for $\mathrm{N}$ and metal Fe atoms into the carbon support, and $\mathrm{Fe}-\mathrm{N}_{\mathrm{x}}-\mathrm{C}$ (Fe bonds with pyridine-N) is the main active sites of the catalyst FeNi-N/C and a synergistic effect of the two sites of $\mathrm{Fe}-\mathrm{N}_{\mathrm{x}}-\mathrm{C}$ and $\mathrm{Ni}-\mathrm{N}_{\mathrm{x}}-\mathrm{C}$ enhances their catalytic activity for ORR further.
\end{abstract}

Keywords Fuel cell · Electrocatalysis · Oxygen reduction reaction (ORR) · FeNi-N/C catalyst · Active sites

\section{Introduction}

With environmental pollution and depletion of energy, it is imperative to develop non-polluting renewable energy sources and seek a kind of green and sustainable energy storage. Fuel cells have attracted much attention because they are green energy conversion technologies that directly convert chemical energy into electrical energy, which have the advantages of high energy density, safety and environmental protection [1-3]. However, the actual operating efficiency of the fuel cell is greatly reduced due to the slow kinetics and the high overpotential and the large energy required to consume in the bond cleavage of the cathodic oxygen reduction process [4]. As an ORR catalyst, the following basic characteristics are necessary: high activity, good durability and cost effectivity. However, the currently used precious metal platinum (Pt) catalyst has low reserves, high cost, easy poisoning and deactivation, which severely limits its large-scale application in fuel cells [5]. Hence, it is necessary to develop a non-precious metal catalyst which is inexpensive, efficient and stable.

In recent years, a large number of non-precious metal catalysts have been extensively studied. Among them, nitrogen-doped carbon-supported transition metal (M-N/ C) catalysts ( $\mathrm{M}=\mathrm{Co}, \mathrm{Fe}, \mathrm{Ni}, \mathrm{Mn}$, etc.) are considered to be the most potential alternatives to replace the noble metal

\footnotetext{
Electronic supplementary material The online version of this article (https://doi.org/10.1007/s42452-020-2651-1) contains supplementary material, which is available to authorized users.

Rong Zhang, zhangrong@tyut.edu.cn | 'Department of Applied Chemistry, School of Chemistry and Engineering, Taiyuan University of Technology, 79 Ying Jersey Street, Shanxi 030024, People's Republic of China.
} 
Pt-based catalysts due to their low price, good activity and good stability [6-11]. In the M-N/C catalysts, the valence electrons of the transition metal are in the $d$ orbital which is adjacent to the Fermi level, and the filling of electrons in the $d$ orbital changes the relative position of the $d$ orbital center and the Fermi level, exhibiting various catalytic activities $[12,13]$. In addition, bonding of transition metal to nitrogen and being embedded easily of nitrogen atom to transition metal vacancies can improve the $d$-band structure and change the electron density of the $d$-band and reduce the Fermi level of the transition metal, in which the metal nitride provides the catalytic active site and excellent catalytic performance [14, 15]. Carbon materials have become the most popular catalyst carriers due to their high specific surface area, abundant energy storage, low cost and good stability. There are many carbon carriers commonly used such as activated carbon, carbon nanotubes, graphene, carbon nanorods, carbon fibers, etc. [16-19]. The nitrogen-doping in carbon layer may cause a positive charge on adjacent $C$ atoms and change the charge and spin density distribution of adjacent carbon atoms, which facilitates the adsorption of oxygen molecular on the adjacent carbon of nitrogen atom in the ORR process [20,21]. Nitrogen sources currently used are polyaniline, melamine, dicyandiamide, ammonia, porphyrin, imidazole, pyrrole, etc.[22-25].

Among the $\mathrm{Fe}-\mathrm{N} / \mathrm{C}$ catalysts, it is currently believed that pyridine- $\mathrm{N}$, pyrrole- $\mathrm{N}$, quaternary ammonium salts $\mathrm{N}, \mathrm{Fe}_{3} \mathrm{C}$ and $\mathrm{Fe}-\mathrm{N}_{\mathrm{x}}$ are sites of catalytic ORR activity [16, 26-32]. However, the active site of the Fe-N/C catalysts is still under debate today. For example, Wang [26] considered that high content of pyridine- $\mathrm{N}$ can effectively increase the spin density and $p$-state density of carbon atoms, and thus it is considered that pyridine- $\mathrm{N}$ is the active site. Zhou et al. [31] conducted two control experiments: immersing FeNGC-950 in $0.5 \mathrm{M} \mathrm{H}_{2} \mathrm{SO}_{4}$ for $12 \mathrm{~h}$ to remove $\mathrm{Fe} / \mathrm{Fe}_{3} \mathrm{C}$ and using $\mathrm{SCN}^{-}$ion strongly combined with $\mathrm{Fe}$ in $\mathrm{Fe}-\mathrm{N}_{\mathrm{x}}$ to destroy and remove $\mathrm{Fe}-\mathrm{N}_{\mathrm{x}}$, which demonstrated that the $\mathrm{Fe} / \mathrm{Fe}_{3} \mathrm{C}$ and $\mathrm{Fe}-\mathrm{N}_{\mathrm{x}}$ groups are both active sites of the ORR catalyst. He et al. [32] pointed out that the active site of $\mathrm{Fe}_{3} \mathrm{C}$ has good oxygen absorption capacity and electrocatalytic activity for ORR.

In the metal-nitrogen-carbon catalysts, it is found that bimetallic catalysts have better catalytic activity and stability than single metal catalysts [27, 33-37]. For instance, $\mathrm{Li}$ et al. [33] pointed out that the addition of $\mathrm{Cu}$ in the $\mathrm{Fe}-\mathrm{N}-\mathrm{C}$ catalyst can promote the interaction between the metal $\mathrm{Fe}$ and $\mathrm{N}$ and increase the content of the surface active sites of the catalyst, leading to the improvement of the performance of the catalyst. So far, the FeNi-N/C bimetallic catalysts are mostly studied with their oxides, and the preparation method is more complicated [38-41]. Independent of the mechanism or nature of the active site, previous researches $[33,42-44]$ have shown that the nature and amount of metal, pyrolysis temperature, carbon support, $\mathrm{N}$-rich polymer and ligand structure are key parameters determining the ORR activity of the catalyst.

In this paper, abundant and easily available $\mathrm{FeCl}_{3} \cdot 6 \mathrm{H}_{2} \mathrm{O}$ and $\mathrm{Ni}(\mathrm{OAc})_{2} \cdot 4 \mathrm{H}_{2} \mathrm{O}$ were selected as bimetallic sources, dicyandiamide (DCD) as nitrogen source and BP2000 as carbon source. A series of FeNi-N/C-t catalysts were prepared by simple ultrasonic-assisted liquid phase reaction and then high temperature heat treatment. The electrochemical experiments show good catalytic activity of this kind of catalysts for ORR in alkaline medium. The influencing factors were explored about metal nature and content, pyrolysis temperature and nitrogen content (Online Resource). In particular, the active sites of the as-prepared catalysts are explored through studying the relationship of the structure and catalytic performance.

\section{Experiment section}

\subsection{Catalyst preparation}

Dicyandiamide (DCD), BP2000, Ferric chloride hexahydrate $\left(\mathrm{FeCl}_{3} \cdot 6 \mathrm{H}_{2} \mathrm{O}\right)$, Nickel acetate tetrahydrate $\left(\mathrm{Ni}(\mathrm{OAC})_{2} \cdot 4 \mathrm{H}_{2} \mathrm{O}\right)$, $\mathrm{HNO}_{3}, \mathrm{NaOH}$, tetrahydrofuran (THF) and methanol $\left(\mathrm{CH}_{3} \mathrm{OH}\right)$ were analytical grade and used as received without further purification. Before the experiment, BP2000 was pretreated with $63 \% \mathrm{HNO}_{3}$ for $24 \mathrm{~h}$ to increase the number of functional groups and improve their surface activity [19]. DCD of $0.4 \mathrm{~g}$ was weighed and dissolved in $50 \mathrm{~mL}$ ethanol at room temperature for $30 \mathrm{~min}$. Then slowly add $\mathrm{FeCl}_{3} \cdot 6 \mathrm{H}_{2} \mathrm{O}$ and $\mathrm{Ni}(\mathrm{OAC})_{2} \cdot 4 \mathrm{H}_{2} \mathrm{O}$ in ethanol solution and ultrasonically react for $60 \mathrm{~min}$ (the total mass of the added metals is $10 \%$ of the total mass of carbon carrier, and the Fe: Ni ratio is 3:1). Finally, $0.4 \mathrm{~g}$ of pretreated carbon support BP2000 was added and sonicated for $60 \mathrm{~min}$. The resulting mixture is dried and heat-treated in a singletube fixed carbon furnace under the protection of $\mathrm{N}_{2} \cdot \mathrm{N}_{2}$ is continuously introduced at the speed of $10{ }^{\circ} \mathrm{C} \mathrm{min}-1$ to heat the furnace at the set temperature for $2 \mathrm{~h}$. After the temperature of the tube furnace is lowered to room temperature, the catalyst is obtained, which is denoted as FeNi-N/C-t, where $t$ is the heat treatment temperature. As a control, a single metal iron and nickel catalyst were prepared according to the above method, respectively: $\mathrm{Fe}-\mathrm{N} / \mathrm{C}-\mathrm{t}$ and $\mathrm{Ni}-\mathrm{N} / \mathrm{C}-\mathrm{t}$.

\subsection{Material characterization}

Surface structure of the catalysts is conducted by X-ray photoelectron spectroscopy (XPS Shimadzu Kratos AXIS ULTRA DLD). Al target (148.6 eV), X-ray gun working at 
$12 \mathrm{kV} \times 15 \mathrm{~mA}$ power, analysis chamber background vacuum $2 \times 10^{-7} \mathrm{~Pa}$, and the data was corrected by contaminated carbon C $1 \mathrm{~s}(284.8 \mathrm{eV})$. The material phase (particle size, crystal structure) was analyzed by X-ray diffraction (XRD Japan Shimadzu LabX-XRD-6000).The $\mathrm{Cu}$ target was selected as the Ka radiation source. The molecular structure of the catalyst was analyzed by Fourier transform infrared spectroscopy (FT-IR TENSOR27).

The electrochemical performance test was carried out using the Shanghai Chenhua CHI660E electrochemical workstation. A three-electrode system was used, the modified glassy carbon used as the work electrode, the saturated calomel electrode (SCE) as reference and 213type platinum plate electrode as auxiliary electrode. The current polarity of CVs and i-t is Cathodic Positive, and the current polarity of LSV is Anodic Positive. Scan from the Negative. The working electrode was prepared as follows: The $12 \mathrm{mg}$ catalyst was added in $0.2 \mathrm{~mL}$ THF solution with ultrasonic treatment for 8 min to obtain evenly dispersed suspension. Use a micro syringe to absorb 3.0 $\mu \mathrm{L}$ and evenly apply it to the center of the glass carbon electrode. After air drying at room temperature, apply $3.0 \mu \mathrm{L} 0.5 \%$ Nafion/ethanol solution. The loading of catalysts was $257 \mu \mathrm{g} \mathrm{cm}^{-1}$. Commercial $20 \mathrm{wt} \% \mathrm{Pt} / \mathrm{C}$ electrode was prepared following the same procedure for comparison. All the potentials were displayed versus the reversible hydrogen electrode (RHE). Prior to electrochemical testing, the catalyst modified GCE (WE) was scanned 20 times in a $\mathrm{N}_{2}$ saturated $0.1 \mathrm{M} \mathrm{NaOH}$ solution at a scan rate of $100 \mathrm{mV} \mathrm{s}^{-1}$ used to activate the electrode. Before the electrochemical measurements, electrolyte was saturated with $\mathrm{O}_{2}$ or $\mathrm{N}_{2}$ by bubbling, and all electrochemical experiments were carried out at room temperature.

The number of electrons in the catalyzed electrode reaction is calculated according to the $\mathrm{K}-\mathrm{L}$ equation, where the K-L equation is as follows $[45,46]$ :

$\mathrm{J}^{-1}=\mathrm{J}_{\mathrm{k}}^{-1}+\mathrm{J}_{\mathrm{L}}^{-1}=\mathrm{J}_{\mathrm{k}}^{-1}+\left(\mathrm{B} \omega^{1 / 2}\right)^{-1}$

$B=0.62 \mathrm{nFC}_{0} D_{0}^{2 / 3} v^{-1 / 6}$

$\mathrm{J}_{\mathrm{k}}=\mathrm{nFkC}_{0}$

where $J$ is the measured current density, $J_{k}$ and $J_{L}$ are the kinetics current density and the diffusion limit current density respectively. $\omega$ is the angular velocity of the disk electrode ( $\omega=2 \pi N, N$ is the linear velocity), and $n$ is the total electron transfer number. $F$ is the Faraday constant. $C_{o}$ is the bulk concentration of oxygen. $D_{o}$ is the diffusion coefficient of oxygen. $v$ is the dynamic viscosity of the $0.1 \mathrm{M}$ $\mathrm{NaOH}$ electrolyte.

\section{Results and discussion}

In order to understand the composition and crystal structure of the as-prepared catalysts, we performed $X$-ray diffraction and infrared spectroscopy on the catalysts as shown in Fig. 1. Figure 1a shows the XRD patterns of the $\mathrm{Fe}-\mathrm{N} / \mathrm{C}-800, \mathrm{Ni}-\mathrm{N} / \mathrm{C}-800$ and $\mathrm{FeNi}-\mathrm{N} / \mathrm{C}-800$ catalyst, it can be seen from the diffraction pattern that all three catalysts have a broad diffraction peak at $24.5^{\circ}$, corresponding to graphite (002) Peak. The peaks of the catalyst $\mathrm{Ni}-\mathrm{N} / \mathrm{C}-800$ appearing near $44.4^{\circ}, 51.77^{\circ}$ and $76.1^{\circ}$ correspond to the diffraction of the $(111),(200)$ and (220) crystal planes of $\mathrm{Ni}$, respectively, and the peak of $64^{\circ}$ corresponds to the (112) diffraction peak of $\mathrm{Ni}_{2} \mathrm{O}_{3}$. The XRD patterns of Catalyst $\mathrm{Fe}-\mathrm{N} / \mathrm{C}-800$ exhibit the diffraction of $\mathrm{Fe}_{4} \mathrm{~N}$ at $41.3^{\circ}, \mathrm{Fe}_{3} \mathrm{C}$ at $44^{\circ}, \mathrm{a}-\mathrm{Fe}$ and $\mathrm{Fe}_{3} \mathrm{O}_{4}$ at $45^{\circ} \mathrm{Fe}(200)$ at $64.3^{\circ}$ and $\mathrm{Fe}_{3} \mathrm{~N}$ at $76.6^{\circ}$. While the $\mathrm{FeNi}$ bimetal catalyst FeNi-N/C-800 has diffraction peaks at $43.4^{\circ}$ for $\mathrm{Fe}_{3} \mathrm{~N}$, at $51^{\circ}$ for $\mathrm{Fe}_{3} \mathrm{C}$, at $64.5^{\circ}$ for both of $\mathrm{Fe}(200)$ and $\mathrm{Ni}_{2} \mathrm{O}_{3}$ and at $76.6^{\circ}$ for $\mathrm{Fe}_{3} \mathrm{~N}$. It is indicated that the bimetal catalyst FeNi-N/C-800 contains $\mathrm{Fe}-\mathrm{N}, \mathrm{Fe}-\mathrm{C}, \mathrm{Ni}-\mathrm{O}$ bonds.

From the FT-IR spectrum as Fig. $1 \mathrm{~b}$ it can be seen that the BP2000 carbon carrier exhibits a $C=0$ stretching vibration peak near $1730 \mathrm{~cm}^{-1}$, indicating that the oxygen-containing groups have being introduced into the surface of BP2000 carbon carrier by the pretreatment with $\mathrm{HNO}_{3}$ and they are favorable for the adsorption of oxygen by the catalyst [20,21]. The peaks at 3432 and $1384 \mathrm{~cm}^{-1}$ of the as-prepared catalysts represent the stretching vibration and deformation vibration of $\mathrm{O}-\mathrm{H}$, respectively. The $\mathrm{Fe}-\mathrm{N} / \mathrm{C}-800, \mathrm{Ni}-\mathrm{N} / \mathrm{C}-800$ and FeNi-N/C-800 catalysts showed a weak peak near $1500 \sim 1600 \mathrm{~cm}^{-1}$ attributed to the vibration of $\mathrm{C}=\mathrm{C}$ and $\mathrm{C}=\mathrm{N}$ bond, indicating that nitrogen was successfully doped into carbon (Proofs from the XPS analysis shown as below). The peak around $1045 \mathrm{~cm}^{-1}$ of the catalyst $\mathrm{FeNi}-\mathrm{N} / \mathrm{C}-800$ is the deformation vibration of $\mathrm{C}-\mathrm{O}$.

In order to understand the effect of temperature on the composition of the catalyst, we performed the TG/ DTA on FeNi-N/C. As seen from Fig. 1c, the first stage is from room temperature to $123^{\circ} \mathrm{C}$, the sample weight loss is $1.23 \%$, mainly due to the loss of adsorbed water. The second stage loses $10.27 \%$ from $123^{\circ} \mathrm{C}$ to $243{ }^{\circ} \mathrm{C}$, mainly due to the loss of crystal water in the catalyst and the decomposition of part of nickel acetate (decomposition temperature $210^{\circ} \mathrm{C}$ ). The third stage loses $21.73 \%$ from $243{ }^{\circ} \mathrm{C}$ to $481^{\circ} \mathrm{C}$. This process is mainly the continued decomposition of nickel acetate, the decomposition of DCD and the partial decomposition of the complex formed by metal DCD. The fourth stage loses $19.18 \%$ from $482^{\circ} \mathrm{C}$ to $670^{\circ} \mathrm{C}$, this stage is likely to be the further 

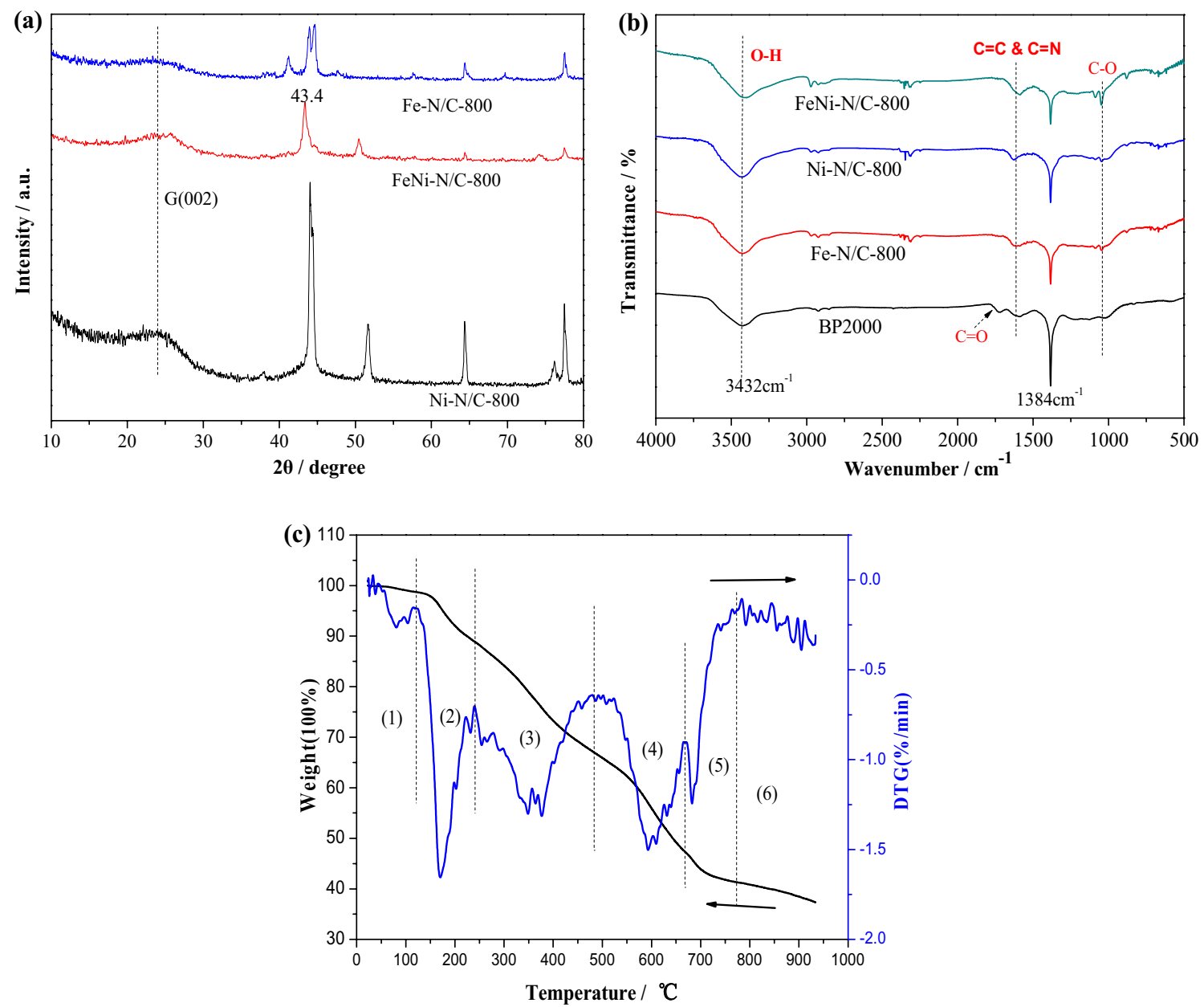

Fig. 1 a XRD of Fe-N/C-800,Ni-N/C-800 and FeNi-N/C-800. b FT-IR spectra of BP2000,Fe-N/C-800, Ni-N/C-800 and FeNi-N/C-800. c TG/DTG curves of the FeNi-N/C catalyst precursor performed at a heating rate of $10{ }^{\circ} \mathrm{C} \mathrm{min}^{-1}$ under flowing high purity of $\mathrm{N}_{2}\left(50 \mathrm{~mL} \mathrm{~min}^{-1}\right)$

decomposition of the complex of metal and DCD on the surface of the carbon support and the cleavage of the carbon support to form a catalytically active site. The fifth stage is from $670{ }^{\circ} \mathrm{C}$ to $778^{\circ} \mathrm{C}$, the weight loss is $6.39 \%$. In this process, the metal complex continues to cleave on the surface of the carbon support to further form a catalytic active site. In the sixth stage, from 778 to $934{ }^{\circ} \mathrm{C}$, the catalyst continues to crack on the surface of the carbon support, accompanied by gasification of carbon atoms, and finally the mass is about $37.32 \%$.

In order to investigate the catalytic activity of the catalysts, the catalysts were electrochemically tested (Fig. 2). Figure $2 \mathrm{a}$ shows the $\mathrm{CV}$ curves of FeNi-N/C-800 catalyst in $0.1 \mathrm{M} \mathrm{NaOH}$ electrolyte under saturated $\mathrm{N}_{2}$ and $\mathrm{O}_{2}$. It can be seen that a significant reduction peak appears at $0.76 \mathrm{~V}$ (vs. $\mathrm{RHE}$ ) under saturated $\mathrm{O}_{2}$, indicating that the FeNi-N/C-800 catalyst has excellent ORR catalytic performance. Figure $2 \mathrm{~b}$ and $\mathrm{c}$ are $\mathrm{CV}$ and LSV curves of $\mathrm{Fe}-\mathrm{N} / \mathrm{C}-800, \mathrm{Ni}-\mathrm{N} / \mathrm{C}-800$ and FeNi-N/C-800 (JM 20\%Pt/C was added to LSV curves for reference only. The electrochemical active areas of $\mathrm{Fe}-\mathrm{N} / \mathrm{C}-800, \mathrm{Ni}-\mathrm{N} / \mathrm{C}-800$ and FeNi-N/C-800 were $0.391,0.167$ and $0.212 \mathrm{~cm}^{2}$, respectively.). The catalysts $\mathrm{Fe}-\mathrm{N} / \mathrm{C}-800$ and $\mathrm{FeNi}-\mathrm{N} / \mathrm{C}-800$ have obvious ORR peaks from the Fig. $2 \mathrm{~b}$, while the $\mathrm{Ni}-\mathrm{N} / \mathrm{C}-800$ catalyst has not obvious ORR peak. As seen Fig. 2c, the bimetal catalyst FeNi-N/C-800 has the more positive onset potential $\left(\mathrm{E}_{\text {onest }}=0.965 \mathrm{~V}\right)$ and the halfwave potential $\left(E_{1 / 2}=0.721 \mathrm{~V}\right)$ compared with the single metal Fe-N/C-800 $\left(\mathrm{E}_{\text {onest }}=0.894 \mathrm{~V}, \mathrm{E}_{1 / 2}=0.680 \mathrm{~V}\right)$ and $\mathrm{Ni}-\mathrm{N} / \mathrm{C}-800\left(\mathrm{E}_{\text {onest }}=0.827 \mathrm{~V}, \mathrm{E}_{1 / 2}=0.590 \mathrm{~V}\right)$. At a potential of $0.3 \mathrm{~V}$, the current density of the FeNi-N/C-800 catalyst was $6.32 \mathrm{~mA} \mathrm{~cm}^{-2}$. Figure $2 \mathrm{~d}$ is the kinetics current density of JM 20\%Pt/C, Fe-N/C-800, Ni-N/C-800 and FeNi-N/C-800. According to Eq. (1) of K-L, the kinetics current density at the determined potential can be calculated (The $\mathrm{J}$ corresponding to $0.3 \mathrm{~V}$ is taken as the $\mathrm{J}_{\mathrm{L}}$ ). It can be clearly seen that compared with $\mathrm{Fe}-\mathrm{N} / \mathrm{C}-800$ and $\mathrm{Ni}-\mathrm{N} / \mathrm{C}-800$, the kinetic current density of FeNi-N/C-800 is $4.585 \mathrm{~mA} \mathrm{~cm}^{-2}$ 

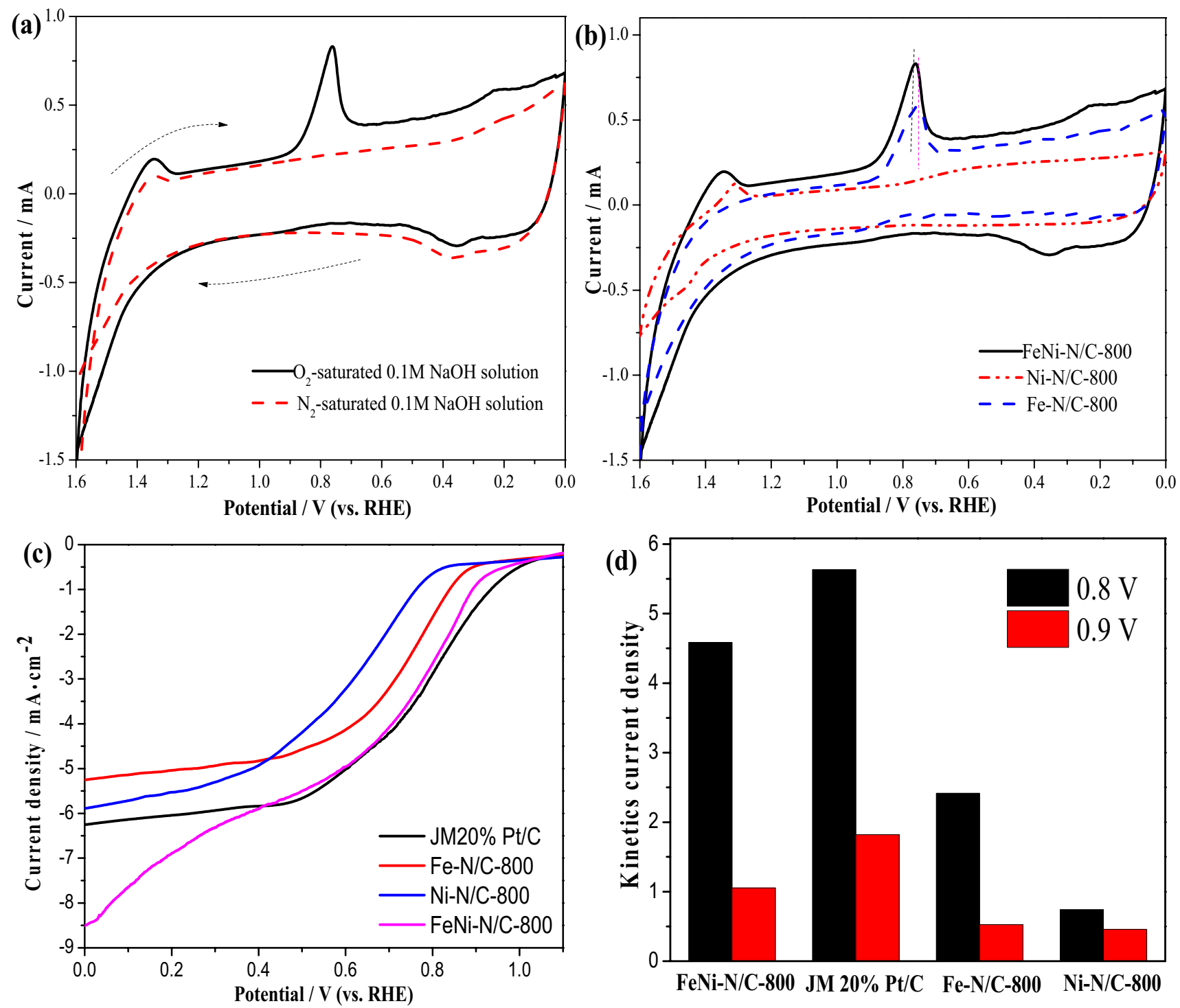

Fig. 2 a CV curves of the catalyst FeNi-N/C-800 in $0.1 \mathrm{M} \mathrm{NaOH}$ under saturated $\mathrm{N}_{2}$ and $\mathrm{O}_{2}$, scan rate: $5 \mathrm{mV} \mathrm{s}^{-1}$. b, c CV and LSV curves of JM 20\%Pt/C, Fe-N/C-800, Ni-N/C-800 and FeNi-

and $1.053 \mathrm{~mA} \mathrm{~cm}^{-2}$ at $0.8 \mathrm{~V}$ and $0.9 \mathrm{~V}$, respectively, which is similar to $\mathrm{JM} 20 \% \mathrm{Pt} / \mathrm{C}\left(0.8 \mathrm{~V}=5.631 \mathrm{~mA} \mathrm{~cm}^{-2}\right.$, $0.9 \mathrm{~V}=1.819 \mathrm{~mA} \mathrm{~cm}^{-2}$ ). It can be seen from the Fig. 2 that the FeNi bimetallic catalyst has better catalytic performance than the Fe and Ni single metal catalysts.

At present, commercial $\mathrm{Pt} / \mathrm{C}$ catalysts have excellent catalytic performance for oxygen reduction. However, in direct methanol fuel cell, methanol will permeate from anode to cathode, causing simultaneous oxidation of methanol and reduction of oxygen at the cathode, generating mixed potential and reducing the cathode potential. Meanwhile, the intermediate particle $\mathrm{CO}$ generated in the methanol oxidation process is also easy to poison $\mathrm{Pt} / \mathrm{C}$, resulting in decreased stability of the catalyst and thus

$\mathrm{N} / \mathrm{C}-800$ in $\mathrm{O}_{2}$-saturated $0.1 \mathrm{M} \mathrm{NaOH}$, scan rate: $5 \mathrm{mV} \mathrm{s}^{-1}$, rotation speed:1600 rpm. d The kinetics current density of JM $20 \% \mathrm{Pt} / \mathrm{C}$, FeN/C-800, Ni-N/C-800 and FeNi-N/C-800 (vs. RHE)

reduced fuel cell efficiency [5]. Therefore, it is necessary to evaluate the methanol cross-resistance of the catalyst. The methanol tolerance of FeNi-N/C-800 and Pt/C was evaluated by the $\mathrm{i}-\mathrm{t}$ measurement with a certain amount of $1 \mathrm{M}$ methanol in $\mathrm{O}_{2}$-saturated $0.1 \mathrm{M} \mathrm{NaOH}$ solution (Fig. 3a). It can be seen from the Fig. 3a that the presence of methanol does not change the catalytic ORR current on FeNi-N/C-800 catalyst, while that does greatly change the ORR current on the commercial JM 20\%Pt/C catalyst, indicating that the as-prepared catalyst FeNi-N/C-800 has unparalleled good methanol tolerance over $\mathrm{Pt} / \mathrm{C}$ catalyst. In order to further study the stability of the catalyst, the plots of the response $\mathrm{i}-\mathrm{t}$ exhibit in Fig. 3b. Figure $3 \mathrm{~b}$ shows a continuous test chart of catalyst FeNi-N/C-800 and 

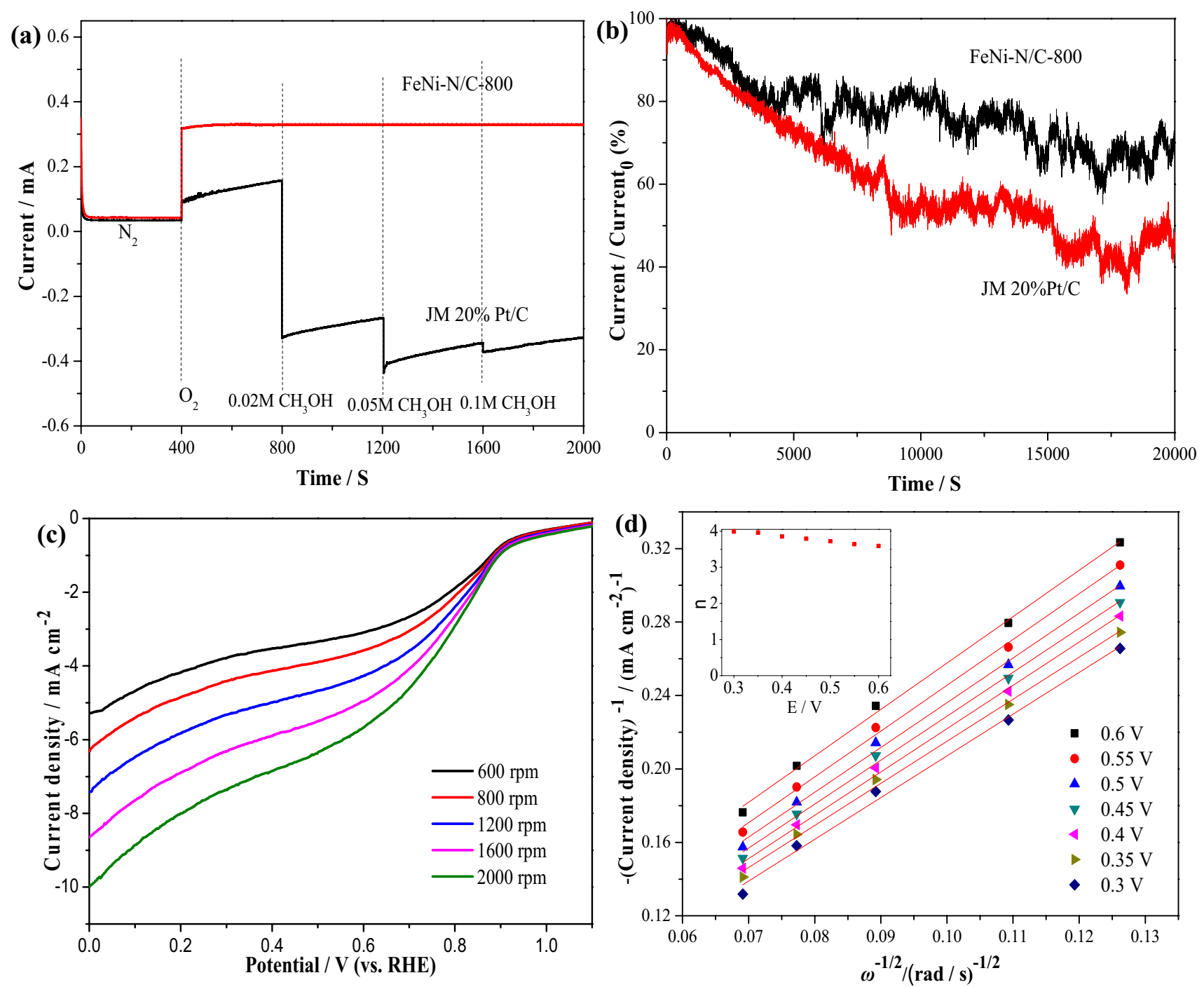

Fig. 3 a Methanol resistant test of the catalysts FeNi-N/C-800 and JM 20\%Pt/C. b i-t responses obtained on the FeNi-N/C-800 and JM $20 \% \mathrm{Pt} / \mathrm{C}$ electrodes at $0.7 \mathrm{~V}$ in $\mathrm{O}_{2}$-saturated $0.1 \mathrm{M} \mathrm{NaOH}$, rotation speed: $800 \mathrm{rpm}$. c LSV curves of FeNi-N/C-800 with different rota-

tion rates in $\mathrm{O}_{2}$-saturated $0.1 \mathrm{M} \mathrm{NaOH}$, scan rate: $5 \mathrm{mV} \mathrm{s}^{-1}$. d K-L plots of oxygen reduction on FeNi-N/C-800, Insert: Electron transfer number of ORR at different potentials on FeNi-N/C-800 catalyst

$20 \% \mathrm{Pt} / \mathrm{C}$ in $\mathrm{O}_{2}$-saturated $0.1 \mathrm{M} \mathrm{NaOH}$ solution for $6 \mathrm{~h}$. It can be seen that the stability of the FeNi-N/C-800 catalyst is significantly better than that of the JM $20 \% \mathrm{Pt} / \mathrm{C}$ catalyst.

Figure $3 \mathrm{C}$ shows the LSV curves of the FeNi-N/C-800 catalyst at the range of $600-2000 \mathrm{rpm}$ in $\mathrm{O}_{2}$-saturated $0.1 \mathrm{M} \mathrm{NaOH}$. It can be seen from Fig. $3 \mathrm{c}$ that limiting current density of the catalyst increases with the rotational speed, because the ORR process is mainly controlled by the diffusion of the reactants, thereby improving mass transfer facilitates the reaction on the surface of the electrode. In the range of about $0.3 \mathrm{~V}$ to $0.6 \mathrm{~V}$, the curves of $J^{-1}-\omega^{-1 / 2}$ are linear and approximately parallel, indicating that the reaction is a first-order kinetics behavior, and the catalyst material is uniformly dispersed on the

electrode surface in the study potential range. Therefore, the number of transferred electrons can be calculated according to the $\mathrm{K}-\mathrm{L}$ equation. Figure $3 \mathrm{~d}$ shows the relationship between $J^{-1}$ and $\omega^{-1 / 2}$ in the range of $0.3 \mathrm{~V}$ to $0.6 \mathrm{~V}$. It can be seen that $J^{-1}$ has a good linear relationship with $\omega^{-1 / 2}$ and substantially parallel, indicating the same reaction mechanism at different potentials [47]. The number of transferred electrons of ORR at different potentials is in the range of 3.59 to 3.98 , as shown in the inset of Fig. $3 \mathrm{~d}$. It can be concluded that the electro-catalytic ORR process on the catalyst FeNi-N/C-800 is a process of mixing $2 \mathrm{e}^{-}$and $4 \mathrm{e}^{-}$and the $4 \mathrm{e}^{-}$process predominates, in which oxygen molecules are mainly reduced into water. 
In order to reveal the active site of the catalyst FeNi$\mathrm{N} / \mathrm{C}$ - $\mathrm{t}$ in the catalytic ORR process, the XPS survey spectras of as-prepared catalysts FeNi-N/C-800, Fe-N/C-800, $\mathrm{Ni}-\mathrm{N} / \mathrm{C}-800$ and N/C-800 were performed (Fig. 4a) and compared with the data of the polarization curves in the catalytic ORR (Fig. 4b). The surface elements and their contents of the catalysts are listed in Table 1 form the Fig. 4a. It can be seen that these as-prepared catalysts contain carbon, oxygen, nitrogen and the corresponding metal (iron or/and nickel) atoms. And it can be also seen from the inset of Fig. $4 \mathrm{a}$ that the bonding energy of peak of $\mathrm{C} 1 \mathrm{~s}$ of the asprepared catalysts are higher than that the $284.8 \mathrm{eV}$ of carbon blank (corrected by contaminated carbon C $1 \mathrm{~s}$ ), which may be caused by the nitrogen and metal atoms doped on the surface of the carbon support. As can be seen in Fig. $4 \mathrm{~b}$ that the $E_{\text {onest }}$ and $E_{1 / 2}$ for ORR decrease in the sequence of the catalysts FeNi-N/C-800, Fe-N/C-800, Ni-N /C-800 and $\mathrm{N} / \mathrm{C}-800$, and the current densities of the ORR of the catalysts at the same potential are all optimal for FeNi-N/C-800. Because the $\mathrm{E}_{\text {onest }}$ and $\mathrm{E}_{1 / 2}$ of $\mathrm{Fe}-\mathrm{N} / \mathrm{C}-800$ are significantly higher than $\mathrm{Ni}-\mathrm{N} / \mathrm{C}-800$ and $\mathrm{N} / \mathrm{C}-800$, and the limiting current density is similar of the three catalysts, so the order of ORR activity of the four catalysts can be arranged as $\mathrm{FeNi}-\mathrm{N} / \mathrm{C}-800>\mathrm{Fe}-\mathrm{N} / \mathrm{C}-800>\mathrm{Ni}-\mathrm{N} / \mathrm{C}-800>\mathrm{N} / \mathrm{C}-800$.

From Table 1 it is found that the nitrogen content of the metal-free catalyst N/C-800 is $2.20 \%$, which is higher than the nitrogen content of the single metal catalyst Fe-N/C- 800 of $1.42 \%$, but the activity of the catalyst N/C800 is not as good as that of $\mathrm{Fe}-\mathrm{N} / \mathrm{C}-800$, indicating that the metal is the active component of the catalyst and the total content of nitrogen on the catalyst surface is not the key factor affecting the activity of the catalysts. Comparing the XPS data and catalytic activity of two single metal catalysts $\mathrm{Fe}-\mathrm{N} / \mathrm{C}-800$ and $\mathrm{Ni}-\mathrm{N} / \mathrm{C}-800$, it can be seen that the nature of the metal has an effect on the catalytic ORR activity, the catalytic activity of the single metal catalyst is $\mathrm{Fe}>\mathrm{Ni}$ in this work. The nitrogen content of the bimetallic catalyst FeNi-N/C-800 is $2.63 \%$, which is much higher than the nitrogen content of $1.42 \%$ of $\mathrm{Fe}-\mathrm{N} / \mathrm{C}-800$. It is shown that the doping of metal $\mathrm{Ni}$ in single metal Fe catalyst can significantly increase the nitrogen content of the catalyst FeNi-N/C-800, indicating that the metal $\mathrm{Ni}$ is likely to be a (a)

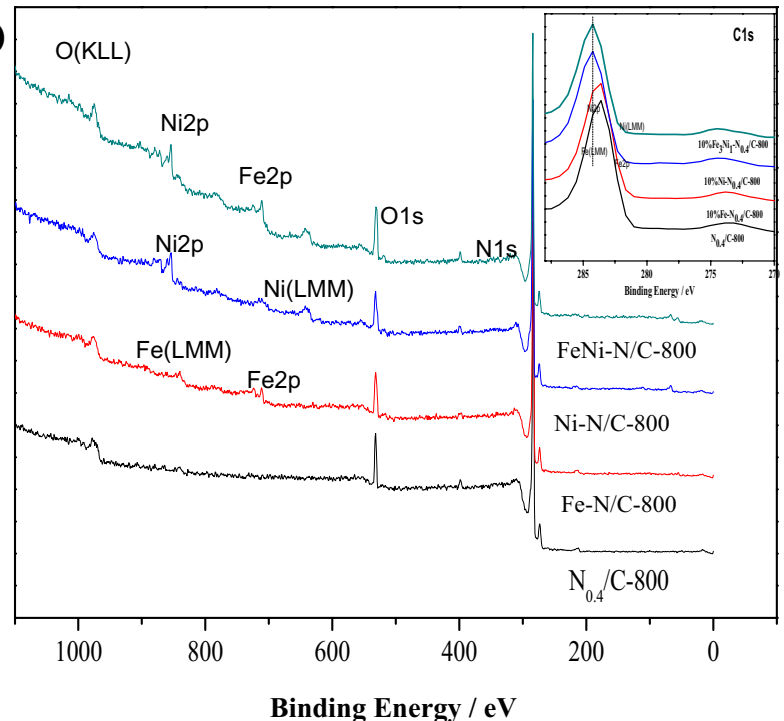

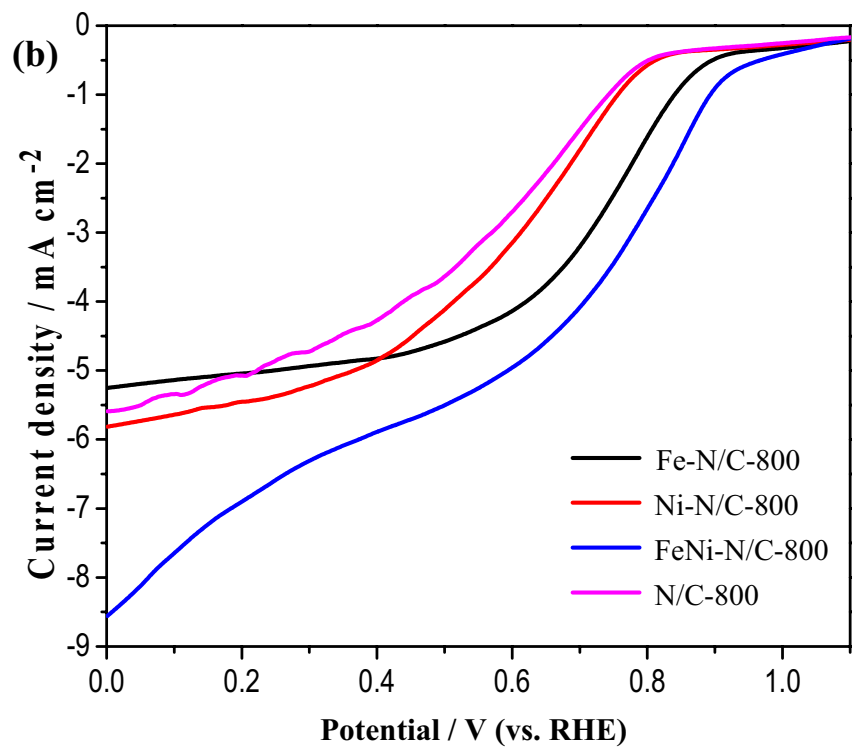

Fig. 4 a XPS survey spectra and insert $\mathrm{C} 1 \mathrm{~s}$ of catalyst FeNi-N/C-800, Fe-N/C-800, Ni-N/C-800 and N/C-800. b LSV curves of FeNi-N/C-800, $\mathrm{Fe}-\mathrm{N} / \mathrm{C}-800, \mathrm{Ni}-\mathrm{N} / \mathrm{C}-800$ and $\mathrm{N} / \mathrm{C}-800$ in $\mathrm{O}_{2}$-saturated $0.1 \mathrm{M} \mathrm{NaOH}$, rotation rate: $1600 \mathrm{rpm}$, scan rate: $5 \mathrm{mV} \mathrm{s}^{-1}$

Table 1 Surface element contents (at. \%) and their ratios of the catalysts from XPS analysis

\begin{tabular}{llllllllll}
\hline Catalysts & $\mathrm{C}^{\mathrm{a}}$ (at.\%) & $\mathrm{O}^{\mathrm{a}}$ (at.\%) & $\mathrm{N}^{\mathrm{a}}$ (at.\%) & $\mathrm{Fe}^{\mathrm{a}}$ (at.\%) & $\mathrm{Ni}^{\mathrm{a}}$ (at.\%) & $\begin{array}{l}\mathrm{O} / \mathrm{C} \text { (atomic } \\
\text { ratio } \times 100 \%)\end{array}$ & $\begin{array}{l}\mathrm{N} / \mathrm{C}(\text { atomic } \\
\text { ratio } \times 100 \%)\end{array}$ & $\begin{array}{l}\mathrm{Fe} / \mathrm{C}(\text { atomic } \\
\text { ratio } \times 100 \%)\end{array}$ & $\begin{array}{l}\mathrm{Ni} / \mathrm{C}(\text { atomic } \\
\text { ratio } \times 100 \%)\end{array}$ \\
\hline $\mathrm{N} / \mathrm{C}-800$ & 90.81 & 6.99 & 2.20 & - & - & 7.7 & 2.4 & - & - \\
$\mathrm{Fe}-\mathrm{N} / \mathrm{C}-800$ & 89.82 & 8.03 & 1.42 & 0.72 & - & 8.9 & 1.6 & 0.8 & - \\
$\mathrm{Ni}-\mathrm{N} / \mathrm{C}-800$ & 88.79 & 7.66 & 2.41 & - & 1.15 & 8.6 & 2.7 & - & 1.3 \\
$\mathrm{FeNi}-\mathrm{N} / \mathrm{C}-800$ & 85.12 & 9.93 & 2.63 & 1.32 & 1.00 & 11.7 & 3.1 & 1.6 & 1.2 \\
\hline
\end{tabular}


co-catalyst, that is, to help more $\mathrm{N}$ atoms enter into carbon layer and bond with Fe atoms. Again, it is seen that the Fe content of the FeNi-N/C-800 (1.32\%) is about twice that of $\mathrm{Fe}-\mathrm{N} / \mathrm{C}-800(0.72 \%)$ under a condition of that actual addition amount of $\mathrm{Fe}$ in the catalyst FeNi-N/C-800 is less than that in the catalyst $\mathrm{Fe}-\mathrm{N} / \mathrm{C}-800$. This indicates that the presence of the transition metal $\mathrm{Ni}$ is likely to increase the bonding of Fe and $\mathrm{N}$, thereby increasing the Fe content. In addition, we can see that the oxygen content on the surface of the carbon support increase in the bimetal catalyst FeNi-N/C-800. Studies $[20,21]$ have shown that the presence of oxygen on the surface of the catalyst promotes the physico-chemical adsorption of oxygen molecules, which is beneficial for catalyzing ORR.

Based on the above experimental results, we can conclude that the nitrogen is necessary for this kind of ORR catalysts, but the effect of nitrogen content depends on the situation. Instead, even if the catalyst contains high nitrogen content without metal, its activity is not good. Secondly, high relative iron content is beneficial to the increase of catalytic activity for ORR. It follows that the as-prepared catalyst FeNi-N/C-800 contains $\mathrm{M}-\mathrm{N}_{\mathrm{x}}(\mathrm{M}=\mathrm{Fe}$, $\mathrm{Ni}), \mathrm{C}-\mathrm{N}$ and $\mathrm{C}-\mathrm{N}_{\mathrm{x}}-\mathrm{M}$ structures which probably act as the active sites in the catalyst for ORR. And the $\mathrm{C}-\mathrm{N}_{\mathrm{x}}-\mathrm{Fe}$ or/ and $\mathrm{Fe}-\mathrm{N}_{\mathrm{x}}$ are the main active sites as result of the activity of FeNi-N/C-800 is much higher than that of N/C-800 and $\mathrm{Ni}-\mathrm{N} / \mathrm{C}-800$.

In order to investigate the effect of different $\mathrm{N}$ atom types on the catalytic ORR activity in the catalyst, the $\mathrm{N} 1 \mathrm{~s}$ characteristic peaks of the prepared catalysts were fitted about FeNi-N/C-800, Fe-N/C-800, Ni-N/C-800 and N/C-800 (Fig. 5). And the ratios of different nitrogen types in the four catalysts were calculated and listed in Table 2. It can be seen from Fig. 5 a that there are four $\mathrm{N} 1 \mathrm{~s}$ fitting peaks (a)

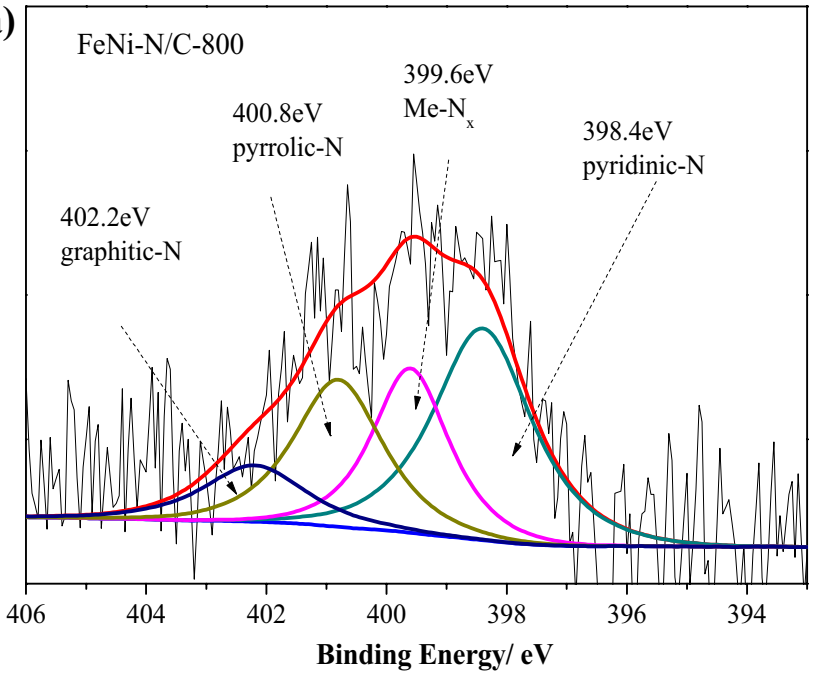

(c)

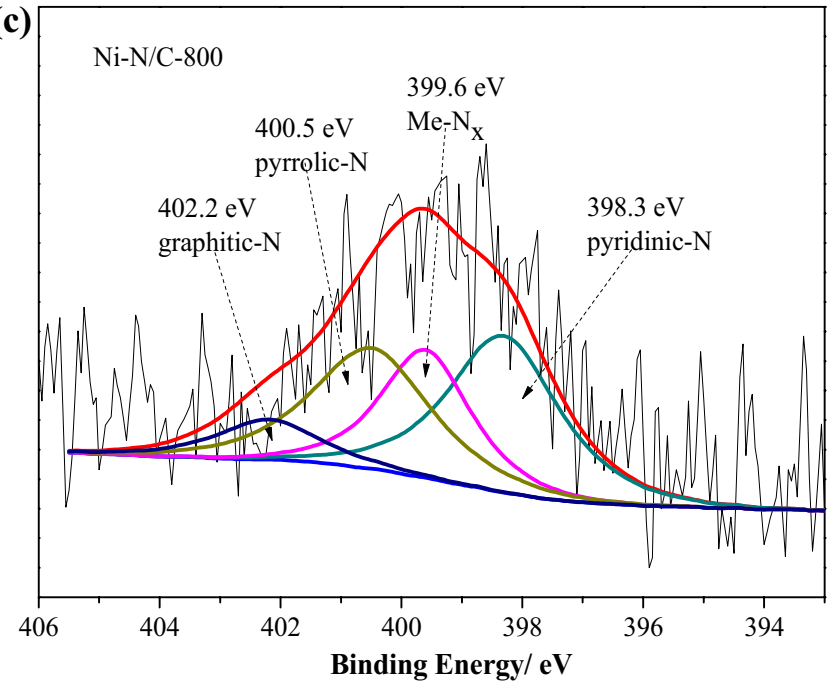

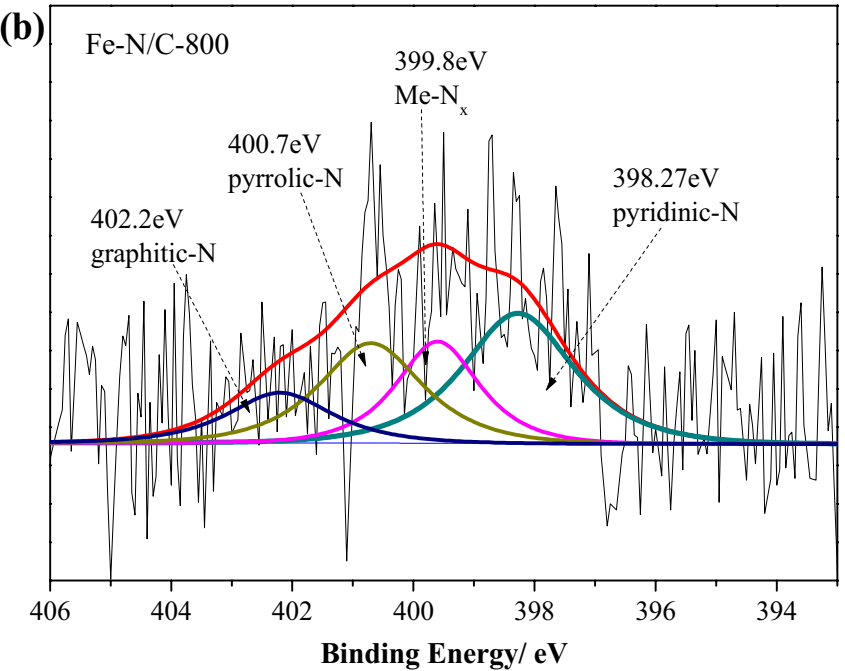

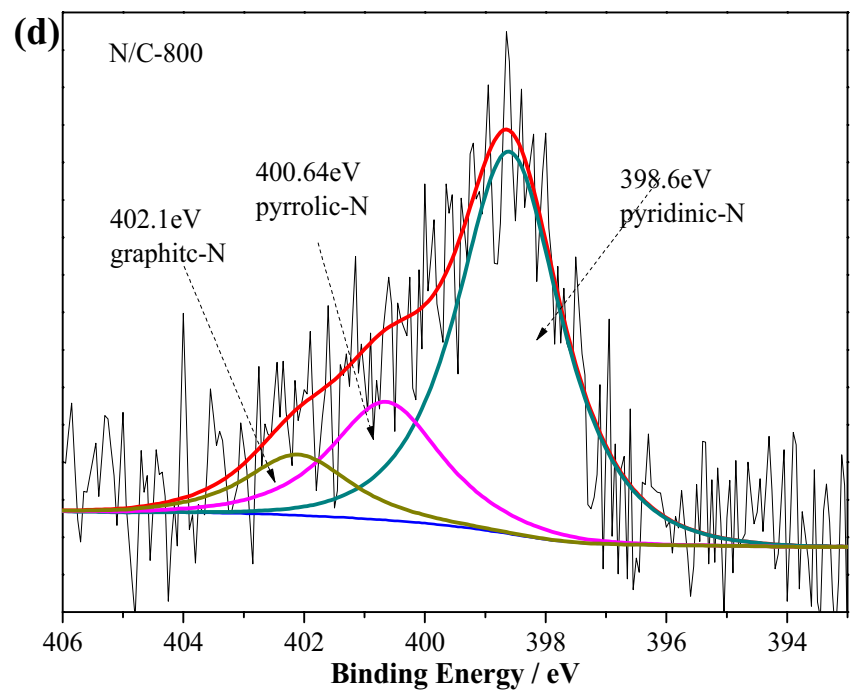

Fig. 5 High-resolution XPS spectra for the N1 s of the (a) FeNi-N/C-800(b) Fe-N/C-800(c) Ni-N/C-800 and (d) N/C-800 
Table 2 The percentage of different types in catalyst N/C-800, Fe$\mathrm{N} / \mathrm{C}-800, \mathrm{Ni}-\mathrm{N} / \mathrm{C}-800$ and FeNi-N/C-800

\begin{tabular}{llllc}
\hline Catalysts & $\begin{array}{l}\text { Pyridinic-N } \\
(\%)\end{array}$ & Me- $\mathrm{N}_{\mathrm{x}}(\%)$ & $\begin{array}{l}\text { Pyrrolic-N } \\
(\%)\end{array}$ & Graphitic-N \\
\hline N/C-800 & 67.2 & 0 & 22.1 & 10.7 \\
Fe-N/C-800 & 37.7 & 21.9 & 26.8 & 13.6 \\
Ni-N/C-800 & 36.7 & 24.3 & 30.2 & 8.8 \\
FeNi- & 39.9 & 24.1 & 25.1 & 10.9 \\
N/C-800 & & & & \\
\hline
\end{tabular}

of the catalyst FeNi-N/C-800, 398.4 eV corresponding to pyridine- $\mathrm{N}$, and $399.6 \mathrm{eV}$ to $\mathrm{M}-\mathrm{N}_{\mathrm{x}}\left(\mathrm{Fe}-\mathrm{N}_{\mathrm{x}}\right.$ or Ni- $\left.\mathrm{N}_{\mathrm{x}}\right), 400.8 \mathrm{eV}$ to pyrrole- $\mathrm{N}$ and $402.2 \mathrm{eV}$ to graphite- $\mathrm{N}$, also indicating the presence of $M-N_{x}$ structure in the catalyst. Figure $5 b$ is the $\mathrm{N} 1 \mathrm{~s}$ high resolution XPS spectrum for $\mathrm{Fe}-\mathrm{N} / \mathrm{C}-800$. There are four fitting peaks at $398.3 \mathrm{eV}, 399.8 \mathrm{eV}, 400.7 \mathrm{eV}$ and $402.2 \mathrm{eV}$ in the catalyst which correspond to pyridine- $\mathrm{N}$, Fe- $\mathrm{N}_{\mathrm{x}}$, pyrrole- $\mathrm{N}$ and graphite- $\mathrm{N}$, respectively. In Fig. $5 c$, the peaks of the $\mathrm{N} 1 \mathrm{~s}$ high resolution XPS spectrum of Ni-N/C-800 are fitted to obtain four peaks of $398.3 \mathrm{eV}$, $399.6 \mathrm{eV}, 400.5 \mathrm{eV}$ and $402.2 \mathrm{eV}$, corresponding to the pyridine- $\mathrm{N}, \mathrm{Ni}-\mathrm{N}_{\mathrm{x}}$, pyrrole- $\mathrm{N}$ and graphite- $\mathrm{N}$, respectively. Figure $5 \mathrm{~d}$ is a high-resolution spectrum of $\mathrm{N} 1 \mathrm{~s}$ of N/C800. The peaks are fitted to obtain three peaks of $398.6 \mathrm{eV}$, $400.6 \mathrm{eV}$ and $402.1 \mathrm{eV}$ assigned to pyridine- $\mathrm{N}$, pyrrole- $\mathrm{N}$ and graphite- $\mathrm{N}$, respectively.

It can be seen from Table 2 that the catalyst N/C-800 contains three types of nitrogen, wherein the pyridine- $\mathrm{N}$ content is $67.2 \%$, which is an absolute advantage, indicating that the activity of the catalyst N/C-800 is mainly derived from pyridine- $\mathrm{N}$. Moreover, its graphite- $\mathrm{N}$ and pyrrole- $\mathrm{N}$ content is similar to the other three catalysts That is, pyridine- $\mathrm{N}$ is the active site of the catalyst N/C800 . Secondly, the content of pyridine-N of the other three catalysts doped with metal was significantly lower than that of N/C-800, but their ORR activity was higher than that of catalyst N/C-800 to varying degrees, indicating that transition metals participated in the composition of catalyst activity sites. At the same time, it is found that compared with the catalyst N/C-800, the content of pyridine- $\mathrm{N}$ of the other three metal-doped catalysts decreased when the $M-N_{x}$ structure appeared, while the content of pyrrole- $\mathrm{N}$ and graphite- $\mathrm{N}$ did not change much. This indicates that $\mathrm{M}-\mathrm{N}_{\mathrm{x}}$ is formed by bonding of the pyridine- $\mathrm{N}$ with the metal atom. It may be that the pyridine- $\mathrm{N}$ is an electron-donating group with a pair of lone electrons, which can form an $\mathrm{M}-\mathrm{N}_{\mathrm{x}}$ structure with the metal. Comparing the content of $\mathrm{M}-\mathrm{N}_{\mathrm{x}}$ and pyridine- $\mathrm{N}$ in three kinds of metal catalysts, the total proportion of pyridine- $\mathrm{N}$ and $\mathrm{M}-\mathrm{N}_{\mathrm{x}}$ in bimetallic catalyst FeNi-N/C-800 is large (about $64 \%)$, and the corresponding catalyst FeNi-N/C-800 has the best catalytic activity for ORR, indicating that the catalytic active sites are mainly pyridine- $\mathrm{N}$ and $\mathrm{M}-\mathrm{N}_{\mathrm{x}}$. Comparing the activity of two single metal catalysts with the content of $\mathrm{M}-\mathrm{N}_{\mathrm{x}}$, it can be seen that the $\mathrm{Ni}-\mathrm{N}_{\mathrm{x}}$ content in $\mathrm{Ni}-\mathrm{N} / \mathrm{C}-800(24.3 \%)$ is slightly larger than the $\mathrm{Fe}-\mathrm{N}_{\mathrm{x}}$ content in $\mathrm{Fe}-\mathrm{N} / \mathrm{C}-800$ (21.9\%), but its catalytic ORR activity is much lower than that of catalyst $\mathrm{Fe}-\mathrm{N} / \mathrm{C}-800$, indicating that the activity of Fe- $\mathrm{N}_{\mathrm{x}}$ is much better than that of $\mathrm{Ni}-\mathrm{N}_{\mathrm{x}^{\prime}}$ in which the nitrogen of $\mathrm{Fe}-\mathrm{N}_{\mathrm{x}}$ and $\mathrm{Ni}-\mathrm{N}_{\mathrm{x}}$ is from pyridine$\mathrm{N}$. Therefore, the active site of catalyst $\mathrm{Fe}-\mathrm{N} / \mathrm{C}-800$ should be Fe- $\mathrm{N}_{\mathrm{x}}-\mathrm{C}$ structure. When the three metal-based catalysts contain $\mathrm{M}-\mathrm{N}_{\mathrm{x}}$ with similar content, the activity of the bimetallic catalyst is significantly higher than that of the single metal catalysts, concluding that there is a synergy between the $\mathrm{Fe}-\mathrm{N}_{\mathrm{x}}-\mathrm{C}$ and the $\mathrm{Ni}_{\mathrm{x}}-\mathrm{N}-\mathrm{C}$ structure in the bimetallic catalyst. Based on the above results, the $\mathrm{Fe}-\mathrm{N}_{\mathrm{x}}-$ $\mathrm{C}$ structure is the main active site of the FeNi-N/C-t catalyst and a synergistic effect of the two sites of $\mathrm{Fe}-\mathrm{N}_{\mathrm{x}}-\mathrm{C}$ and $\mathrm{Ni}-\mathrm{N}_{\mathrm{x}}-\mathrm{C}$ enhances their catalytic activity for ORR further.

\section{Conclusion}

In summary, a battery of iron-nickel bimetallic codoped nitrogen-containing carbon catalysts FeNi-N/C$\mathrm{t}$ were prepared by high temperature heat-treatment. The results show that a good activity $\left(E_{\text {onset }}=0.965 \mathrm{~V}\right.$ vs. RHE) for ORR in the alkaline medium is obtained with FeNi-N/C-800, which is close to that of the JM $20 \% \mathrm{Pt} / \mathrm{C}$ catalyst. The electrocatalytic ORR process on this type of catalyst is mainly based on the $4 \mathrm{e}^{-}$reaction mechanism. Namely, the ORR is mainly a process of directly reducing oxygen into water. It is also conclude that the nature of the metal and the heat treatment temperature are important factors affecting the catalytic activity of the prepared catalyst. From XPS and LSV data it was found that $\mathrm{Ni}$ can be regarded as a catalyst for $\mathrm{N}$ atoms and metal Fe into the carbon support, and $\mathrm{Fe}-\mathrm{N}_{\mathrm{x}}-\mathrm{C}$ formed by the pyridine- $\mathrm{N}$ with the metal is the main active sites of the catalyst FeNi-N/C-t for electrocatalytic ORR and a synergistic effect of the two sites of $\mathrm{Fe}-\mathrm{N}_{\mathrm{x}}-\mathrm{C}$ and $\mathrm{Ni}-\mathrm{N}_{\mathrm{x}}-\mathrm{C}$ enhances their catalytic activity for ORR further.

Acknowledgements This study was funded by the Shanxi Province Natural Science Foundation in China (No. 2013011012-1) and the major province research and development project of Shanxi (20181102019).

Author contributions Rong Zhang and Wei Fang conceived and designed the experiments; Wei Fang, Lu Liu and Ruiming Li performed the experiments; Wei Fang wrote the paper; Rong Zhang, Wenyang Wang, Ding Zhang and Zixiang Cui directed the work and revised the manuscript. 


\section{Compliance with ethical standards}

Conflict of interest On behalf of all authors, the corresponding author states that there is no conflict of interest.

\section{References}

1. Arunchander A, Peera SG et al (2017) Synthesis of cobalt sulfidegraphene as an efficient oxygen reduction catalyst in alkaline medium and its application in anion exchange membrane fuel cells. Electrochem Soc 164(2):71-80

2. Gu F, Wang YW et al (2018) Catalytic mechanism of palladium catalyst for the oxidation reduction and evolution reaction of lithium-air battery. J Inorg Mater 33(10):1131-1135

3. Lu CJ, Zhu FQ, Yin JG et al (2018) Synthesis of a $\mathrm{MnO}_{2}$ nanowires via facile hydrothermal method and their application in $\mathrm{Li}_{2} \mathrm{O}_{2}$ battery. J Inorg Mater 33(9):1029-1034

4. Asefa T (2016) Metal-free and noble metal-free heteroatomdoped nanostructured carbons as prospective sustainable electrocatalysts. Acc Chem Res 49:1873-1883

5. Huang XX, Wang YZ, Li W, Hou YL (2017) Noble metal-free catalysts for oxygen reduction reaction. Sci China Chem 60:1494-1507

6. Gu W, Hu L, Hong W, Jia X, Li J, Wang E (2016) Noble-metal-free $\mathrm{Co}_{3} \mathrm{~S}_{4}-\mathrm{S} / \mathrm{G}$ porous hybrids as an efficient electrocatalyst for oxygen reduction reaction. J Chem Sci 7:4167-4173

7. Xu L, Pan G, Shi X (2015) A non-noble material cathode catalyst dual-doped with sulfur and nitrogen as efficient electrocatalysts for oxygen reduction reaction. Electrochim Acta 177:57-64

8. Van Tam T, Kang SG et al (2017) Synthesis of B-doped graphene quantum dots as a metal-free electrocatalyst for the oxygen reduction reaction. J Mater Chem A 5:10537-10543

9. Li R, Wei Z, Gou X, Xu W (2013) Phosphorus-doped graphene nanosheets as efficient metal-free oxygen reduction electrocatalysts. RSC Adv 3:9978-9984

10. Liu S, Yang Z, Liu L et al (2018) Metallic iron doped vitamin B12/C as efficient nonprecious metal catalysts for oxygen reduction reaction. Int J Hydrogen Energy 43:16230-16239

11. Hong W, Li L, Xue R, Xu X et al (2017) One-pot hydrothermal synthesis of zinc ferrite/reduced grapheme oxide as an efficient electrocatalyst for oxygen reduction reaction. J Colloid Interface Sci 485:175-182

12. Hao J, Shi W (2018) Transition metal (Mo, Fe, Co and Ni)-based catalysts for electro-chemical $\mathrm{CO}_{2}$ reduction. Chin J Catal 39:1157-1166

13. Wu J, Nabae $Y$ et al (2016) Electrochemical deposition and dissolution of Fe species for $\mathrm{N}$-doped carbon to understand the degradation mechanism of Pt-free oxygen reduction catalyst. Electrochim Acta 214:307-312

14. Yi M, Hua $Y$, Wang K et al (2018) Enhancement of oxygen reduction reaction performance: the characteristic role of Fe-N coordination. Electrochim Acta 260:264-273

15. Zhang C, Liu J, Ye Y, Aslam Z, Brydson R, Liang C (2018) Fe-Ndoped mesoporous carbon with dual active sites loaded on reduced graphene oxides for efficient oxygen reduction catalysts. ACS Appl Mater Interfaces 10:2423-2429

16. Cazetta AL, Spessato L et al (2019) Metal-free ovalbuminderived N-S-co-doped nanoporous carbon materials as efficient electrocatalysts for oxygen reduction reaction. Appl Surf Sci 467-468:75-83

17. Liu S, Chen X, Wang S et al (2018) 3D CNTs-threaded N-doped hierarchical porous carbon hybrid with embedded $\mathrm{Co} / \mathrm{CoO}_{\mathrm{x}}$ nanoparticles as efficient bifunctional catalysts for oxygen electrode reactions. Electrochim Acta 292:707-717

18. Zhou T, Zhou Y, Ma R, Liu Q, Zhu Y, Wang J (2017) Achieving excellent activity and stability for oxygen reduction electrocatalysis by hollow mesoporous iron-nitrogen-doped graphitic carbon spheres. J Mater Chem A 5(24):12243-12251

19. Zhou N, Li L, Chen S et al (2019) Mesoporous, nitrogen-doped, graphitized carbon nanosheets embedded with cobalt nanoparticles for efficient oxygen electroreduction. J Mater Sci 54:4168-4179

20. Zhu C, Du D, Eychmuler A et al (2015) Engineering ordered and nonordered porous noble metal nanostructures: synthesis, assembly, and their applications in electrochemistry. Chem Rev 115(16):8896-8943

21. Zhu X, Zhu YH, Tian CC et al (2017) Pyrolysis of conjugated nanoporous polycarbazoles to mesoporous $\mathrm{N}$-doped carbon nanotubes as efficient electrocatalysts for the oxygen reduction reaction. J Mater Chem A 5:4507-4512

22. Zhu H, Sun Z, Chen M et al (2017) Highly porous composite based on tungsten carbide and $\mathrm{N}$-doped carbon aerogels for electrocatalyzing oxygen reduction reaction in acidic and alkaline media. Electrochim Acta 236:154-160

23. Chen C, Zhang X, Zhou Z-Y et al (2016) Highly active Fe, N co-doped graphene nanoribbon/carbon nanotube composite catalyst for oxygen reduction reaction. Electrochim Acta 222:1922-1930

24. Sarapuu A, Kreek K et al (2017) Electrocatalysis of oxygen reduction by iron-containing nitrogen-doped carbon aerogels in alkaline solution. Electrochim Acta 230:81-88

25. Kong W, Yao K et al (2018) Holey Co, N-codoped graphene aerogel with in-plane pores and multiple active sites for efficient oxygen reduction. Electrochim Acta 269:544-552

26. Wang R, Yan T, Han L, Chen G, Li H et al (2018) Tuning the dimensions and structures of nitrogen-doped carbon nanomaterials derived from sacrificial g- $\mathrm{C}_{3} \mathrm{~N}_{4} /$ metal-organic frameworks for enhanced electrocatalytic oxygen reduction. J Mater Chem A 6:5752-5761

27. Liu S, Yang Z, Li M, Lv W, Liu L, Wang Y, Chen X, Zhao X, Zhu P, Wang $G$ (2018) Facile synthesis of 3D hierarchical mesoporous Fe-C-N catalysts as efficient electrocatalysts for oxygen reduction reaction. Int J Hydrogen Energy 43:5163-5174

28. Zhang M, Gao J et al (2019) Bimetallic Mn and Co encased within bamboo-like $\mathrm{N}$-doped carbon nanotubes as efficient oxygen reduction reaction electrocatalysts. J Colloid Interface Sci 537:238-246

29. She Y, Chen J et al (2017) Oxygen reduction reaction mechanism of nitrogen-doped graphene derived from ionic liquid. Energy Procedia 142:1319-1326

30. Wu R, Wang J, Chen K et al (2017) Space-confined pyrolysis for the fabrication of $\mathrm{Fe} / \mathrm{N} / \mathrm{C}$ nanoparticles as a high performance oxygen reduction reaction electrocatalyst. Electrochim Acta 244:47-53

31. Zhou T, Ma R, Zhang T et al (2019) Increased activity of nitrogen-doped graphene-like carbon sheets modified by iron doping for oxygen reduction. J Colloid Interface Sci 536:42-52

32. He C, Zhang T et al (2017) Fe/N co-doped mesoporous carbon nanomaterial as an efficient electrocatalyst for oxygen reduction reaction. Electrochim Acta 231:549-556

33. Li J, J Chen J et al (2019) Boosting oxygen reduction activity of Fe-N-C by partial copper substitution to iron in Al-air batteries. Appl Catal B Environ 242:209-217

34. Martinaiou I, Shahraei A, Grimm F et al (2017) Effect of metal species on the stability of Me-N-C catalysts during accelerated stress tests mimicking the start-up and shut-down conditions. Electrochim Acta 243:183-196 
35. Ma X, Chai H, Cao Y et al (2018) An effective bifunctional electrocatalysts: Controlled growth of CoFe alloy nanoparticles supported on N-doped carbon nanotubes. J Colloid Interface Sci 514:656-663

36. Su CY, Cheng H, Li W, Liu ZQ, Li N, Hou ZF, Bai FQ, Zhang HX, Ma TY (2017) Atomic modulation of FeCo-nitrogen-carbon bifunctional oxygen electrodes for rechargeable and flexible all-solidstate zinc-air battery. Adv Energy Mater 7:1602420

37. Wang J, Zhang H, Wang C, Zhang Y et al (2018) Co-synthesis of atomic Fe and few-layer graphene towards superior ORR electrocatalyst. Energy Storage Mater 12:1-7

38. Liao Z, Wang Y et al (2019) Bimetal-phthalocyanine based covalent organic polymers for highly efficient oxygen electrode. Appl Catal B Environ 243:204-211

39. Gui L, Huang Z et al (2019) Insights into Ni-Fe couple in perovskite electrocatalysts for highly efficient electrochemical oxygen evolution. Electrochim Acta 293:240-246

40. Zhu C, Yin Z et al (2018) Fe-Ni-Mo nitride porous nanotubes for full water splitting and Zn-air batteries. Adv Energy Mater 8:36

41. Du J, Yu A et al (2018) One-pot synthesis of iron-nickel-selenide nanorods for efficient and durable electrochemical oxygen evolution. Inorg Chem Front 5(4):814-818

42. Roncaroli F, Dal Molin ES et al (2015) Cobalt and iron complexes with $\mathrm{N}$-heterocyclic ligands as pyrolysis precursors for oxygen reduction catalysts. Electrochim Acta 174:66-77
43. Lv Q, Si W et al (2017) Nitrogen-doped porous graphdiyne: a highly efficient metal-free electrocatalyst for oxygen reduction reaction. ACS Appl Mater 9:29744-29752

44. Vezzù K, Delpeuch AB et al (2016) Fe-carbon nitride "core-shell" electrocatalysts for the oxygen reduction reaction. Electrochim Acta 222:1778-1791

45. Wang $\mathrm{Y}$, Liu $\mathrm{H}$ et al (2017) 3D interconnected hierarchically porous $\mathrm{N}$-doped carbon with $\mathrm{NH}_{3}$ activation for efficient oxygen reduction reaction. J Appl Catal B 210:57-66

46. Cui XZ, Zhang LL, Zeng LM et al (2018) Fabrication of tungsten carbide nanoparticle-encased graphite-like mesoporous carbon as a precious metal-free electrocatalyst for oxygen reduction. $J$ Inorg Mater 33(2):213-220

47. Zhang HJ, Li HL, Li XT et al (2014) Porolyzing cobalt diethylenetriamine chelate on carbon (CoDETA/C) as a family of non-precious metal oxygen reduction catalyst. Int J Hydrogen Energy $39: 267-276$

Publisher's Note Springer Nature remains neutral with regard to jurisdictional claims in published maps and institutional affiliations. 